\title{
The Catabolism of Cystathionine by Escherichia coli
}

\author{
BY S. WIJESUNDERA* AND D. D. WOODS \\ Microbiology Unit, Department of Biochemistry, University of Oxford
}

(Received 10 February 1962)

\begin{abstract}
SUMMARY
$\mathrm{L}$-Cystathionine is rapidly degraded to homocysteine, pyruvate and ammonia by cell-free enzyme preparations of an auxotrophic strain of Escherichia coli which requires pyridoxin, glycine or serine for growth. One molecule of each of the products was formed from each molecule of cystathionine throughout the course of the reaction. The preparation did not form pyruvate from $\mathrm{L}$-serine and L-alanine (which were possible intermediates); it is concluded that the cleavage is a single step reaction. After precipitation with ammonium sulphate and dialysis the enzyme required both pyridoxal phosphate and magnesium ions for full activity, but no dependence on magnesium was found with preparations from another strain. The reaction was inhibited totally by cyanide and cupric ions and partially by isonicotinic acid hydrazide and sulphydryl compounds (cysteine, homocysteine, glutathione). An auxotrophic strain of $E$. coli which grew with methionine or homocysteine, but not with cystathionine, did not contain the enzyme.
\end{abstract}

\section{INTRODUCTION}

The nutritional requirements of certain induced mutants of Escherichia coli (Lampen, Roepke \& Jones, 1947; Gots \& Koh, 1950) suggest that cysteine is converted to methionine, as in Neurospora (Horowitz, 1947), through the successive intermediate formation of cystathionine (Fig. 3) and homocysteine. The conversion of homocysteine to methionine by $E$. coli has been studied extensively in this laboratory, with suspensions of intact organisms and with cell-free enzyme preparations (Gibson \& Woods, 1960; Guest \& Woods, 1962). There is little detailed information, however, about the bacterial metabolism of cystathionine, the probable immediate precursor of homocysteine. Binkley \& Hudgins (1953) stated briefly that cell-free preparations of Proteus morganii degraded cystathionine both to homocysteine and to cysteine, the former pathway being predominant with concurrent formation of pyruvate and ammonia; pyridoxal phosphate was required. The object of the present work, which forms part of a wider study of methionine synthesis by $E$. coli, was to determine whether this organism has the necessary enzymic mechanisms to convert cystathionine to homocysteine and to investigate the nature and course of the reaction. An auxotrophic strain (B 166) which requires pyridoxin for growth was used initially in the hope of facilitating the study of any requirement for this vitamin in its coenzyme form (pyridoxal phosphate). A brief report of part of this work has been given (Wijesundera \& Woods, 1953).

In mammalian liver cystathionine is degraded mainly to cysteine and $\alpha$-keto-

* Present address: Department of Biochemistry, University of Ceylon, Colombo 8, Ceylon. 
butyrate and not to homocysteine and pyruvate (Binkley, Anslow \& du Vigneaud, 1942; Carroll, Stacey \& du Vigneaud, 1949). This enzyme has been highly purified (Matsuo \& Greenberg, 1958 $a$ ) and shown also to require pyridoxal phosphate (Binkley, Christensen \& Jensen, 1952; Matsuo \& Greenberg, 1958b, 1959a). The work of Fischer (1957) with cell-free preparations of Neurospora crassa suggests that this organism can degrade cystathionine by both pathways, that leading to homocysteine being the major one.

\section{METHODS}

Organisms. Escherichia coli B 166, an auxotroph requiring either pyridoxin, serine or glycine for growth in a medium containing autoclaved glucose (Morris \& Woods, 1959) was the main organism used; it was obtained originally from $\operatorname{Dr} J$. S. Gots. E. coli 122/33 and 26/18 (both from Dr B. D. Davis) were methionine auxotrophs responding respectively to cystathionine or homocysteine (122/33) and homocysteine only (26/18). E. coli $\mathbf{F}$ was a prototrophic laboratory strain. Stock cultures of all the organisms were maintained on tryptic digest of meat agar slopes, subcultured monthly $\left(18 \mathrm{hr}\right.$. at $\left.37^{\circ}\right)$ and stored at $4^{\circ}$.

Media and growth. Medium L (Morris \& Woods, 1959), containing lactate as carbon source, was used for strain F. Medium A, used for the auxotrophic strains, was the glucose + salts medium of Davis \& Mingioli (1950) except that the glucose (and any necessary growth factor) was added before autoclaving. With strain B 166 it was desired to obtain organisms grown without added pyridoxin; although either DL-serine or glycine alone will support growth under these conditions, best yields were obtained with a mixture of DL-serine, glycine and DL-alanine (each $\mathrm{mM}$ ). The supplement used for strains $122 / 33$ and $26 / 18$ was DL-methionine (0.5 mM).

The appropriate medium $\left(500 \mathrm{ml}\right.$. in $1 \mathrm{l}$. Roux bottles) was autoclaved at $115^{\circ}$ for $10 \mathrm{~min}$. and inoculated with $0.5 \mathrm{ml}$. of a $24 \mathrm{hr}$. culture in the same medium. The Roux bottles were incubated at $37^{\circ}$ for $16-20 \mathrm{hr}$. in a sloped position $\left(20^{\circ}\right.$ to the horizontal) to increase aeration. Organisms from 20-30 bottles were harvested in a continuous centrifuge, washed twice on an angle centrifuge with $100 \mathrm{ml}$. volumes of phosphate buffer (67 mM, pH 7·4) and stored (when necessary) as a thick paste at $4^{\circ}$.

Cell-free extracts. Organisms (equiv. $1 \mathrm{~g}$. dry wt.) in $8 \mathrm{ml}$. phosphate buffer $(67 \mathrm{mM}, \mathrm{pH} \mathrm{7 \cdot 4)}$ ) were placed in each cup of a tissue disintegrator (Mickle, 1948) with 8 g. glass balls (Ballotini no. 13; Chance Bros., Smethwick, Staffs.) and tributyl citrate $\left(0.1 \mathrm{ml}\right.$.). The cups were vibrated at maximum amplitude for $1 \mathrm{hr}$. at $2^{\circ}$ and the crushed organisms washed out with about $25 \mathrm{ml}$. phosphate buffer $(67 \mathrm{~mm}$, $\mathrm{pH} 7 \cdot 4$ ) at $0^{\circ}$. The clear yellowish supernatant fluid obtained by centrifuging for $15 \mathrm{~min}$. at $18,000 \mathrm{~g}$ contained about $85 \%$ of the total enzyme activity of the crushed material. It was stored at $0^{\circ}$ after adding a few drops of chloroform and retained full activity for at least two weeks.

General procedure in experiments with enzymes. The reaction mixture contained enzyme preparation (0.2-1.0 ml.), pyridoxal phosphate $(10 \mu \mathrm{m}$-moles), magnesium sulphate $(1 \mu$ mole $)$, substrate ( $10 \mu$ moles of L- or $20 \mu$ moles of DL-) and phosphate buffer ( $\mathrm{pH} \mathrm{7 \cdot 4)}$ ) to a final volume of $2 \mathrm{ml}$. and final molarity of 0.067 . The substrate solution (at $37^{\circ}$ ) was added after incubating the remaining constituents for $10 \mathrm{~min}$. at $37^{\circ}$; the final incubation was normally for $30 \mathrm{~min}$. at $37^{\circ}$ in tubes $(125 \mathrm{~mm} . \times$ $16 \mathrm{~mm}$.) shaken gently in air. When keto acids were to be assayed or identified the 
reaction was stopped (and proteins precipitated) by the addition of $25 \%(\mathrm{w} / \mathrm{v})$ trichloroacetic acid $(0.5 \mathrm{ml}$.). Protein-free filtrates for the estimation of ammonia and homocysteine were obtained by warming the reaction mixture with an equal volume of $\mathrm{N}-\mathrm{HCl}$.

Chemical estimations. A modification of the method of Friedeman \& Haugen (1943) was used for pyruvic acid. Samples were diluted to $2 \mathrm{ml}$. and mixed with $1 \mathrm{ml}$. of $2 \%(\mathrm{w} / \mathrm{v})$ 2,4-dinitrophenylhydrazine in $2 \mathrm{~N}-\mathrm{HCl}$; after $15 \mathrm{~min}$. at $25^{\circ}$ an equal volume of $2 \cdot 5 \mathrm{~N}-\mathrm{NaOH}$ was added. The absorption of the resulting 2,4-dinitrophenylhydrazone was measured at $450 \mathrm{~m} \mu$ after the colour had fully developed (15 min.). Authentic sodium pyruvate was used as standard and absorption was linear from 0 to $0 \cdot 35 \mu$ mole; test samples outside this range were suitably diluted with $1 \cdot 25 \mathrm{~N}-\mathrm{NaOH}$.

Ammonia was distilled from samples (2.5-3.0 ml.), using the apparatus described by Markham (1942), into $0.5 \%(\mathrm{w} / \mathrm{v})$ boric acid in $20 \%(\mathrm{v} / \mathrm{v})$ ethanol in water containing a mixed indicator (Conway \& O'Malley, 1942); 0.01 N-HCl was used for the titration.

Assay of homocysteine. A microbiological method based on the growth requirement of Escherichia coli 26/18 was used. This strain responds to homocysteine or methionine but not to cystathionine or cysteine. The materials under test were free from methionine as judged by lack of activity when tested $(a)$ in the methionine assay of Gibson \& Woods (1960) with Streptococcus equinus P 60 and (b) with a methionine-requiring auxotroph of $E$. coli (M 200) which does not respond to homocysteine.

The lactones of $L$ - and $D$-homocysteine were equally active in supporting the growth of the test organism; DL-homocysteine, which was more readily available, was therefore used as standard. The following other possible degradation products of L-cystathionine were inactive when tested at 0.1 and $0.5 \mathrm{~mm}$, either alone or in the presence of pyridoxal phosphate $(2 \cdot 5 \mu \mathrm{M})$ : cysteine (tested as $\mathrm{L}$ ), homoserine, serine, alanine, $\alpha$-aminobutyric acid (all tested as $\mathrm{DL}$ ).

Medium A (final volume $4 \mathrm{ml}$. in $150 \mathrm{~mm} . \times 19 \mathrm{~mm}$. tubes) was supplemented with test samples or DL-homocysteine (0.1-0.8 $\mu$ mole) and autoclaved at $115^{\circ}$ for $7 \mathrm{~min}$. The inoculum was about $2 \times 10^{3}$ organisms harvested from a fresh $24 \mathrm{hr}$ culture on tryptic digest of meat agar and incubation was for $40 \mathrm{hr}$. at $37^{\circ}$. Extent of growth was assessed in an EEL photoelectric colorimeter (Evans Electroselenium Ltd., Halstead, Essex) with a neutral density filter. The dose-response curve (Fig. 1) was linear in the range $\mathbf{0} \cdot \mathbf{1 - 0 \cdot 3} \mu$ mole DL-homocysteine; the curve for a typical experimental sample could be superimposed on the standard curve throughout the range tested (Fig. 1) thus confirming the authenticity of the assay. The mutant showed a tendency to revert to wild type at low frequency and occasional assays failed because of random full growth in tubes containing sub-optimal quantities of homocysteine.

Chromatography. Amino acids were identified by the use of descending chromatograms developed on Whatman no. 1 paper either with butanol + acetic acid (the upper layer of a mixture of $n$-butanol, glacial acetic acid and water in the proportions $(\mathrm{v} / \mathrm{v})$ of $4+1+5)$ or with phenol + water $(160 \mathrm{~g}$. phenol $+40 \mathrm{ml}$. water). The detecting agent was ninhydrin, and also, in the case of the sulphur-containing amino acids, the platinic iodide reagent of Toennies \& Kolb (1951). 
Keto acids were identified by a modification of the method of Metzler \& Snell $(1952 a)$. The sample $(2 \mathrm{ml}$.) of deproteinized reaction products was mixed with $0.1 \mathrm{ml}$. of $0.2 \%(\mathrm{w} / \mathrm{v})$ 2,4-dinitrophenylhydrazine in $2 \mathrm{~N}-\mathrm{HCl}$. After $10 \mathrm{~min}$. the resulting hydrazone was extracted into ethyl acetate and samples placed on Whatman no. 1 paper on spots previously treated with $0.01 \mathrm{ml}$. phosphate buffer $(67 \mathrm{~mm}, \mathrm{pH} 7 \cdot 4)$. The buffer neutralized any acid carried over and decreased spreading of the spots. The chromatograms were developed with a mixture of $n$-butanol, water and ethanol $(5+4+1$ by vol.) and the hydrazones detected directly as yellow spots; faint spots were seen more easily in ultraviolet radiation.

Chemicals. L-Cystathionine was isolated from the mycelium of Neurospora crassa H $98 \mathrm{~A}$ essentially as described by Horowitz (1947) who found it to be identical with the synthetic compound, i.e. $S$-(L- $\beta$-amino- $\beta$-carboxylethyl) L-homocysteine (Anslow, Simmonds \& du Vigneaud, 1946). Our material darkened with decomposition at $280^{\circ}$ and gave the same $R_{f}$ value as a specimen of synthetic L-cystathionine on chromatograms developed with butanol + acetic acid and phenol + water. It also gave an identical dose-response curve to authentic material when tested with an auxotroph of $N$. crassa (38706) which requires cystathionine, homocysteine or methionine for growth. All other amino acids used were obtained commercially.

\section{RESULTS}

\section{Nature of the reaction}

Identification of products. Homocystine was detected chromatographically $\left(\boldsymbol{R}_{f} \mathbf{0 \cdot 1 2}\right.$ in butanol + acetic acid) in the products of a reaction catalysed by cellfree extracts of Escherichia coli strain B 166; the $R_{f}$ value of the original cystathionine was $0 \cdot 04$. The material also supported the growth of $E$. coli strain 26/18, an auxotroph requiring homocysteine or methionine, and there was excellent correspondence between the response curve given by increasing amounts of the sample and of authentic homocysteine (Fig. 1). Such samples were free from methionine as judged by the tests described in the Methods section.

Cysteine was also a possible product of cystathionine metabolism. It was not, however, detected on chromatograms developed with phenol + water nor did samples of the reaction products support the growth of Streptococcus equinus P 60 on a medium devoid of cysteine (Barton Wright, 1952); in the latter test it was necessary first to confirm chromatographically that all the cystathionine had been removed since it partially replaces cysteine for the growth of the organism.

The presence of a keto acid or acids in the reaction products was indicated by production of a red colour after treatment of deproteinized samples with 2,4-dinitrophenylhydrazine reagent and making alkaline. Chromatography of the hydrazones (see Methods) showed that the keto acid was pyruvic acid (Table 1); the appearance of two spots for each hydrazone is probably due to the different rates of travel of the syn- and anti-isomers of the hydrazones (Metzler \& Snell, 1952a). No spots corresponding with the hydrazone of $\alpha$-ketobutyric acid (another possible product of cystathionine metabolism) were detected. The absorption spectrum (400-600 $\mathrm{m} \mu$ ). given in alkaline solution by the hydrazone formed from the test sample was identical within experimental error with that of the hydrazone of authentic pyruvic 
acid (peak $450 \mathrm{~m} \mu$ ) and differed from that of the $\alpha$-ketobutyric acid derivative (peak $436 \mathrm{~m} \mu)$.

A volatile base giving the characteristic reaction with Nessler's reagent was also formed during the action of the cell-free enzyme preparation on cystathionine; it was assumed to be ammonia.

Course of the reaction. The rate of production of homocysteine, pyruvate and ammonia was linear and, within experimental error, equimolar throughout the course of the reaction (Fig. 2). There was thus no indication of the accumulation of an intermediate. The final values for homocysteine and ammonia corresponded to 1 mole per mole of cystathionine. The value for pyruvate was slightly lower (0.9 mole) and decreased a little on further incubation suggesting the presence in the preparation of enzymes metabolizing pyruvate slowly. For these experiments a

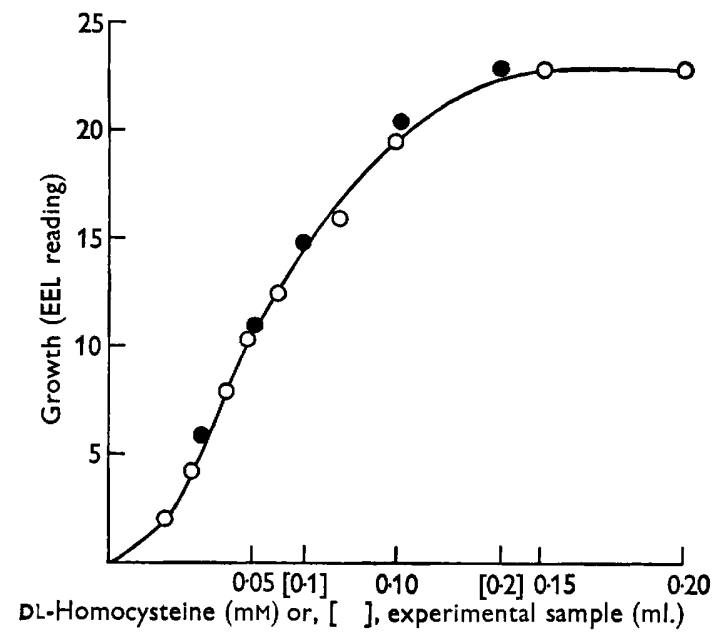

Fig. 1

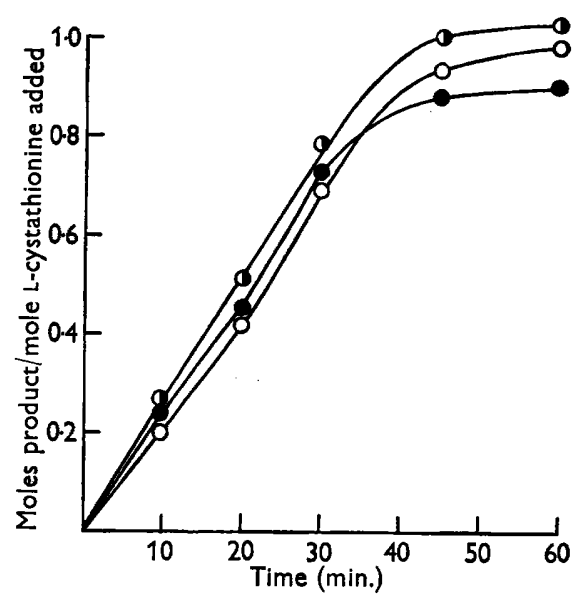

Fig. 2

Fig. 1. Response of Escherichia coli strain $26 / 18$ to DL-homocysteine $(O)$ and to a sample of degradation products of L-cystathionine (O); the sample was obtained after incubating for $30 \mathrm{~min}$. the standard reaction mixture containing L-cystathionine (20 $\mu$ moles) and an enzyme preparation of $E$. coli strain B $166(0.5 \mathrm{ml}$., equiv. $30 \mathrm{mg}$. dry wt. organism).

Fig. 2. Rate of production of homocysteine $(\mathrm{O}-\mathrm{O})$, pyruvate $(\mathrm{O}-\mathrm{O})$ and ammonia (1) - The standard reaction mixture $(20 \mathrm{ml}$.) contained $\mathrm{L}$-cystathionine $(200 \mu \mathrm{moles})$ and an enzyme preparation of Escherichia coli strain B 166 (8 ml., equiv. $400 \mathrm{mg}$. dry wt. organism).

\section{Table 1. Chromatography of the 2,4-dinitrophenylhydrazones of keto-acids}

L-Cystathionine (10 $\mu$ moles) was incubated for $10 \mathrm{~min}$. in the standard reaction mixture with enzyme derived from Escherichia coli strain B 166 (1 ml., equiv. $50 \mathrm{mg}$. dry wt. organism). Samples of the products and of authentic pyruvate and $\alpha$-ketobutyrate (each $10 \mu$ moles) were converted to 2,4-dinitrophenylhydrazones and chromatographed as described in the Methods section.

\begin{tabular}{ll}
\multicolumn{1}{c}{ Material } & $\boldsymbol{R}_{\boldsymbol{f}}$ values \\
Experimental sample & $\mathbf{0 \cdot 5 2 , 0 \cdot 7 1}$ \\
Pyruvate & $\mathbf{0 \cdot 5 3 , 0 \cdot 7 4}$ \\
$\alpha$-Ketobutyrate & $0 \cdot 67,0 \cdot 78$
\end{tabular}


reaction mixture of total volume $20 \mathrm{ml}$. (in a $100 \mathrm{ml}$. conical flask) was used and samples $(2 \mathrm{ml}$.) withdrawn at intervals. Since the microbiological assay of homocysteine was time-consuming and occasionally unreliable (see Methods) the production of pyruvate was used henceforward as a routine for estimating the activity of the enzyme; the method is both convenient and sufficiently sensitive. Endogenous control values were less than with ammonia.
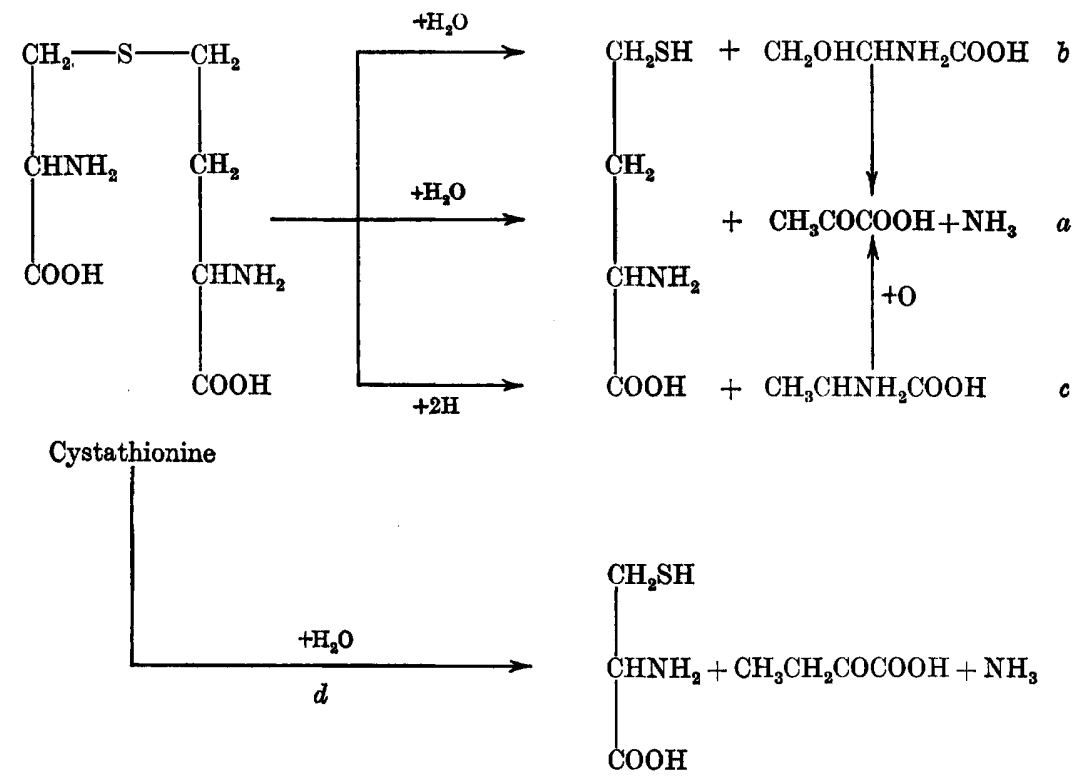

Fig. 3. Possible pathways for the degradation of cystathionine; $(a),(b)$ and $(c)$ refer to the bacterial enzyme while $(d)$ is the pathway probable in animal tissues.

Table 2. Comparative activity of the enzyme with cystathionine, serine and alanine

Substrate (10 $\mu$ moles of $L_{-}-$or $20 \mu$ moles of $\left.\mathrm{DL}-\right)$ was incubated for $30 \mathrm{~min}$. in the standard reaction mixture with enzyme preparation from Escherichia coli strain B 166 $(0.5 \mathrm{ml}$., equiv. $25 \mathrm{mg}$. dry wt. organism).

Pyruvate ( $\mu$ moles) formed in

\begin{tabular}{lcc}
\multicolumn{1}{c}{ Substrate } & Expt. 1 & Expt. 2 \\
None & $\mathbf{0 . 0 0}$ & $\mathbf{0 . 0 0}$ \\
L-Cystathionine & $\mathbf{7 \cdot 1 0}$ & $\mathbf{4 \cdot 3 6}$ \\
DL-Serine & $\mathbf{7 \cdot 3 3}$ & $\mathbf{8 . 8 0}$ \\
L-Serine & - & $<\mathbf{0 . 0 2}$ \\
D-Serine & - & 6.45 \\
DL-Alanine & $\mathbf{0 . 0 7}$ & -
\end{tabular}

Overall mechanism of the reaction. There are three possible types of reaction (Fig. 3) by which cystathionine could by the addition of the elements of water give rise to homocysteine, pyruvate and ammonia: (a) Simultaneous fission of the bond linking the $\mathrm{S}$ atom to the $\mathrm{C}$ atom of the three-carbon chain and deamination of the three-carbon fragment; this would be analogous to the degradation of tryptophan to indole, pyruvate and ammonia by the tryptophanase enzyme of Escherichia coli 
(Wood, Gunsalus \& Umbreit, 1947). (b) Initial hydrolytic cleavage of the above $\mathrm{S}-\mathrm{C}$ bond with formation of homocysteine and serine, the latter being deaminated to pyruvate and ammonia; serine deaminase is known to be present in $E$. coli (Gale \& Stephenson, 1938; Wood \& Gunsalus, 1949; Metzler \& Snell, 1952b). (c) Initial reductive fission of the above $\mathrm{S}-\mathrm{C}$ bond yielding homocysteine and alanine, the latter in turn giving pyruvate and ammonia by oxidative deamination; an oxidative deaminase attacking DL-alanine is also present in $E$. coli (Stephenson \& Gale, 1937).

Little or no pyruvate was formed from DL-alanine (Table 2) but the production of pyruvate from DL-serine somewhat exceeded that from L-cystathionine. Experiments with the individual amino acid isomers however showed that only D-serine was attacked (Table 2); the fact that $D$-serine yielded less pyruvate than the equivalent amount of the DL-compound is accounted for by the known impurity of the

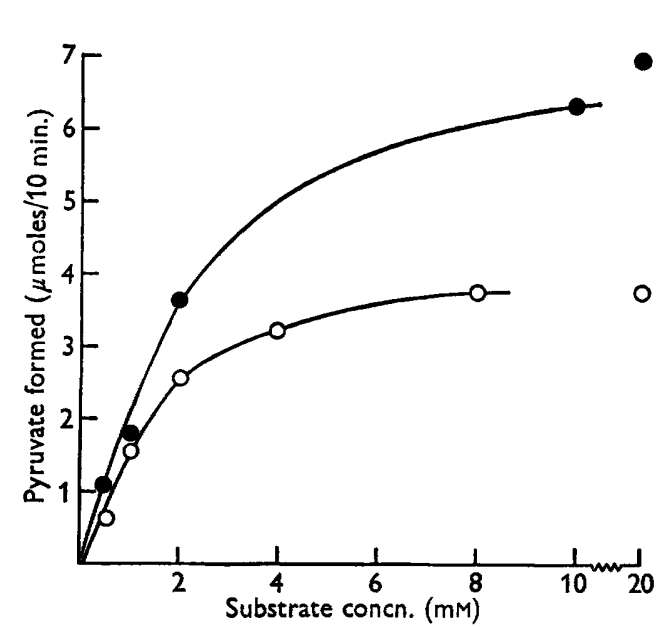

Fig. 4

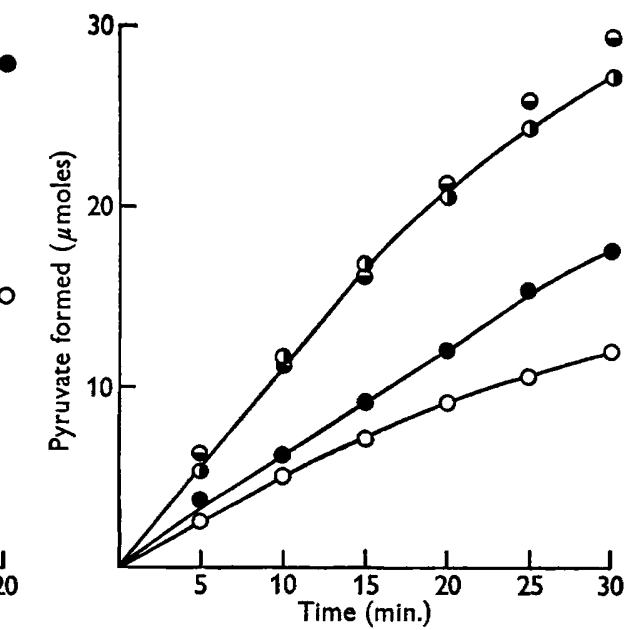

Fig. 5

Fig. 4. Effect of the concentration of L-cystathionine $(\mathrm{O}-\mathrm{O})$ and DL-serine ( - on the initial rate of formation of pyruvate. Cystathionine was omitted from the standard reaction mixture when serine was present: the enzyme preparation $(0.4 \mathrm{ml}$, equiv. 25 mg. dry wt. organism) was obtained from Escherichia coli strain B 166 and had been stored at $0^{\circ}$ for 4 days.

Fig. 5. Rate of production of pyruvate from L-cystathionine $(\mathrm{O}-\mathrm{O})$, DL-serine ( -0$)$ and from a mixture of the two ( - ) . The points $(\theta)$ represent the sum of the individual values for the two substrates. The standard reaction mixture contained $40 \mu \mathrm{moles}$ of each or both substrates and an enzyme preparation $(0.4 \mathrm{ml}$., equiv. $25 \mathrm{mg}$. dry wt. organism) from Escherichia coli strain B 166.

specimen of $\mathbf{D}$-serine used. L-Cystathionine would be expected to yield $\mathrm{L}$-serine or L-alanine; since neither was attacked by an enzyme preparation which formed pyruvate actively from L-cystathionine, it is clear that neither can be a free intermediate in the reaction. This would exclude mechanisms $(b)$ and $(c)$ (Fig. 3) and direct formation of homocysteine, pyruvate and ammonia $(a)$ is therefore probable.

The relation between substrate concentration and initial velocity of the reaction was measured (Fig. 4) both for L-cystathionine and for D-serine (supplied as the DL-compound); the $K_{m}$ values were 1.2 and $1.0 \mathrm{~mm}$, respectively. The rate of for- 
mation of pyruvate was linear from each substrate but, when both were present, each at a concentration ( $20 \mathrm{mM}$ ) sufficient fully to saturate the enzyme, the rate was clearly additive (Fig. 5). It is likely, therefore, that cystathionine and D-serine deaminase activities are not separate functions of the same enzyme. This conclusion is supported by the fact that the ratio of the two activities was different with different enzyme preparations (e.g. Table 2) and that, on prolonged storage at $0^{\circ}$, cystathionase activity was lost more rapidly than that of $\mathrm{D}$-serine deaminase; both enzymes, however, were stable for 2 weeks. Almost complete separation of the two activities was finally achieved by maintaining the preparation at $55^{\circ}$ in phosphate buffer (pH 7.4, $67 \mathrm{~mm}$ ). After $12 \mathrm{~min} .35 \%$ of the D-serine deaminase was lost but cystathionase was unaffected; the former enzyme was entirely lost after $50 \mathrm{~min}$. while about $25 \%$ of the cystathionase activity remained.

\section{Table 3. Effect of pyridoxal phosphate and magnesium ions on the degradation of cystathionine}

The standard reaction mixture contained L-cystathionine (10 $\mu \mathrm{moles)}$ and (where indicated) pyridoxal phosphate or pyridoxal (20 $\mu$ moles), ATP ( $2 \mu$ moles) and metal ions (100 $\mu$ moles). The enzyme ( $1 \mathrm{ml}$., equiv. $40 \mathrm{mg}$. dry wt. organism) was a preparation of Escherichia coli strain B 166 which had been resolved as described in text. Incubation was at $37^{\circ}$ for $30 \mathrm{~min}$.

$\begin{array}{ccc}\text { Additions } & \text { Metal ion } & \begin{array}{c}\text { Pyruvate } \\ \text { formed } \\ (\mu \mathrm{moles})\end{array} \\ \text { 'Coenzyme' } & - & \mathbf{0 . 0 1} \\ - & - & \mathbf{0 \cdot 3 0} \\ \text { Pyridoxal phosphate } & \mathbf{M g}^{2+} & \mathbf{0 \cdot 1 8} \\ \text { Pyridoxal phosphate } & \mathbf{M g}^{2+} & \mathbf{2 \cdot 1 0} \\ \text { Pyridoxal phosphate } & \mathbf{M n}^{2+} & \mathbf{0 . 5 2} \\ \text { Pyridoxal phosphate } & \mathbf{Z n}^{2+} & \mathbf{0 . 3 7} \\ \text { Pyridoxal + ATP } & \mathbf{M g}^{2+} & \mathbf{0 . 1 8}\end{array}$

Effect of pyridoxal phosphate. Initial experiments were carried out with enzyme preparations of Escherichia coli strain B 166 harvested after growth in absence of vitamin $\mathbf{B}_{6}$ derivatives (see Methods) and therefore presumably deficient in this vitamin. Suspensions of the organism grown similarly have been shown to require vitamin $\mathbf{B}_{6}$ absolutely for the conversion of homocysteine to methionine, with serine as source of the one-carbon residue (Wijesundera, Cross \& Woods, 1960). In the present case pyruvate formation from cystathionine by the cell-free enzyme was increased $50-100 \%$ by pyridoxal phosphate $(5 \mu \mathrm{M})$. Complete resolution of the enzyme was achieved by storing a preparation for five days at $0^{\circ}$ followed by

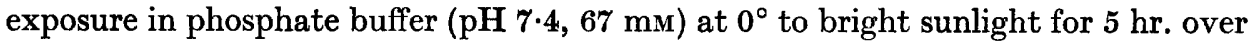
a period of 2 days. The enzyme was then precipitated by saturation with ammonium sulphate and the precipitate redissolved in water and dialysed for $20 \mathrm{hr}$. at $4{ }^{\circ}$ against running water. The preparation now had negligible activity but was activated by a mixture of pyridoxal phosphate and magnesium ions (Table 3); alone each had only a small effect. Pyridoxal plus adenosine triphosphate did not replace pyridoxal phosphate. Manganous and zinc ions replaced magnesium only partially. It was then found that complete resolution with regard to pyridoxal phosphate could be obtained with enzyme preparations of Escherichia coli $\mathrm{F}$ simply by dialysis after storage for 5 days at $0^{\circ}$; the requirement for magnesium ions was not shown. With 
such preparations cystathionase activity increased almost linearly with pyridoxal phosphate concentration from 0 to $10 \mu \mathrm{M}$ (Fig. 6); the $K_{m}$ was about $8 \mu \mathrm{M}$.

Temperature and $\mathrm{pH}$. The optimum temperature for the cystathionase reaction in phosphate buffer at $\mathrm{pH} 7 \cdot 4$ was $42^{\circ}$; activity decreased to $26 \%$ at $30^{\circ}$ but only to $86 \%$ at $50^{\circ}$. The effect of $\mathrm{pH}$ was studied in three buffers (Fig. 7); the optimum $\mathrm{pH}$ in tris buffer (8.6) was rather higher than in phosphate and borate (8.2).

Inhibitors. Sulphydryl compounds (cysteine, homocysteine, reduced glutathione) markedly inhibited cystathionase activity though sulphide itself had only a small effect (Table 4); homocysteine is also of course one of the reaction products. Isonicotinic acid hydrazide, which is sometimes regarded as an antimetabolite of the vitamin $\mathbf{B}_{6}$ group, was also strongly inhibitory; cyanide and cupric ions caused total inhibition (Table 4).

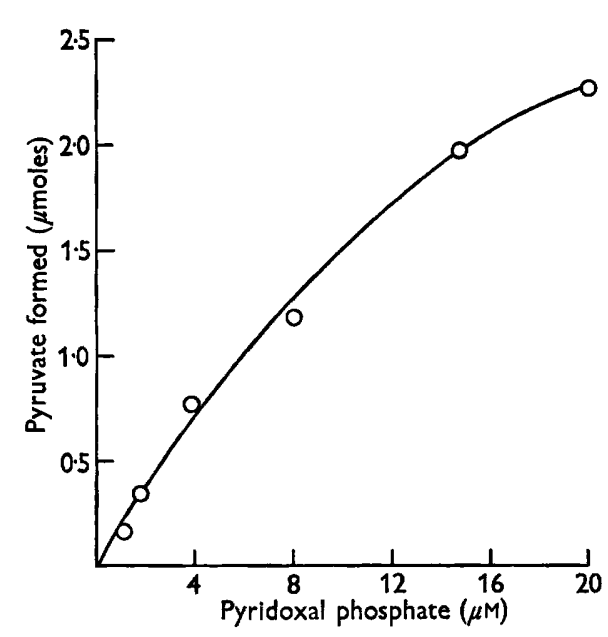

Fig. 6

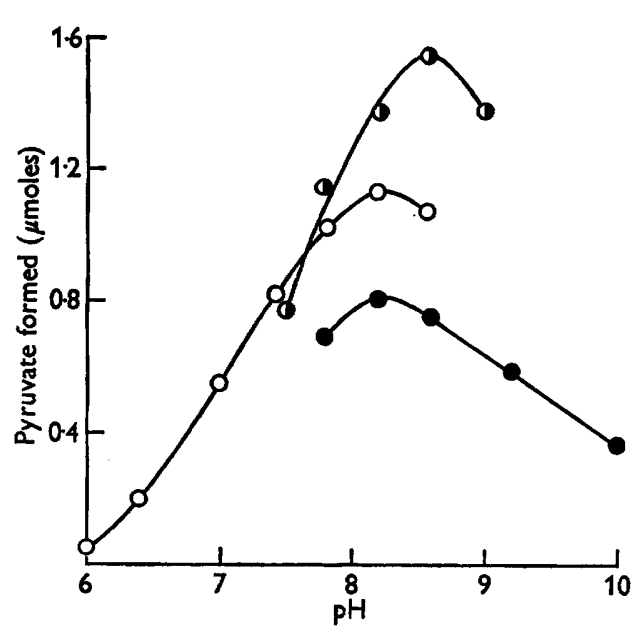

Fig. 7

Fig. 6. Effect of the concentration of pyridoxal phosphate on cystathionase activity. The standard reaction mixture was modified by increasing the pH value to 8.2 and the amount of $\mathrm{Mg}^{2+}$ to $0.1 \mathrm{~m}$-mole. The enzyme preparation (0.5 ml.; equiv. $25 \mathrm{mg}$. dry wt. organism) was obtained from Escherichia coli strain $\mathbf{F}$ and had been dialysed after storage for 5 days at $0^{\circ}$. Pyridoxal phosphate was incubated for $10 \mathrm{~min}$. with the reaction mixture before adding $\mathrm{L}$-cystathionine $(10 \mu$ moles $)$ and incubating at $37^{\circ}$ for a further 30 min.

Fig. 7. Effect of $\mathrm{pH}$ value on the activity of cystathionase in phosphate $(\mathrm{O}-\mathrm{O})$, borate $(-\bigcirc)$ and tris $(0-\infty)$ buffers. The phosphate in the standard reaction mixture was replaced as required by borate or tris of equivalent concentration. The enzyme preparation (0.5 ml. from equiv. $25 \mathrm{mg}$. dry wt. organism, of Escherichia coli strain F) had been dialysed to remove phosphate. Time of incubation (37 $) 15$ min.

\section{Cystathionase in other strains of Escherichia coli}

Escherichia coli strain 122/33 is a methionine auxotroph which also grows when given homocysteine or cystathionine; as expected, it contained the cystathionase enzyme though this was rather less active (or less easily extracted) than that of strains B 166 and F (Table 5). The main interest, however, centred on methionine auxotrophs which respond to homocysteine but not to cystathionine. Such organisms (e.g. strain 26/18) would be expected not to contain the enzyme; this 
proved to be the case (Table 5). Many cases are known, however, in which the genetic block is incomplete or in which the lesion results in an enzyme with changed properties (Mitchell, 1953). The properties of strain 26/18 were therefore re-examined under a variety of conditions. Cystathionine did not support growth when glucose (medium A) was replaced by lactate (medium $\mathrm{L}$ ) as sole carbon source or when incubation was at $30^{\circ}$ instead of $37^{\circ}$ on either medium. Furthermore, no cystathionase activity was detected in cell-free extracts at any $\mathrm{pH}$ value between 6 and

\section{Table 4. Inhibition of cystathionine degradation}

The standard reaction mixture contained L-cystathionine (10 $\mu$ moles) and enzyme derived from Escherichia coli strain B $166(0.25 \mathrm{ml}$., equiv. $12 \mathrm{mg}$. dry wt. organism) and was incubated for $15 \mathrm{~min}$. in the presence or absence of the substances indicated. Unless otherwise stated, sodium salts were used. Results are expressed as \% decrease in pyruvate formed compared with controls containing no inhibitor.

\begin{tabular}{lcc}
\multicolumn{1}{c}{ Addition } & $\begin{array}{c}\text { Concn. } \\
(\mathrm{mM})\end{array}$ & $\begin{array}{c}\text { Inhibition } \\
(\%)\end{array}$ \\
Cyanide & $\mathbf{1}$ & $\mathbf{1 0 0}$ \\
Copper sulphate & $\mathbf{1}$ & $\mathbf{1 0 0}$ \\
Isonicotinic acid hydrazide & $\mathbf{1}$ & $\mathbf{8 7}$ \\
Glutathionine (reduced) & $\mathbf{5}$ & $\mathbf{5 6}$ \\
DL-Homocysteine & $\mathbf{1 0}$ & $\mathbf{6 5}$ \\
L-Cysteine & 10 & $\mathbf{4 5}$ \\
Azide & 10 & $\mathbf{2 0}$ \\
Sulphide & 10 & 11 \\
Fluoride & 10 & $\mathbf{0}$ \\
Arsenate & 10 & $\mathbf{0}$
\end{tabular}

Table 5. Cystathionase activity of extracts of strains of Escherichia coli

The standard reaction mixture contained $0.25 \mathrm{ml}$. (equiv. $13 \mathrm{mg}$. dry wt. organism) of cell-free extracts derived from the $E$. coli strains indicated and was incubated at $37^{\circ}$ for $15 \mathrm{~min}$. The results given are the mean values from at least three experiments.

Strain
of $E$. coli
F
B 166
$122 / 33$
$26 / 18$

Growth requirement

None; prototrophic

Pryridoxal, serine or glycine

Methionine, homocysteine or cystathionine

Methionine or homocysteine

* No activity was again observed when the amount of enzyme preparation and the time of incubation were both increased fourfold.

10, in phosphate or borate buffer as appropriate. Possible lack of an additional cofactor was tested by supplementing the reaction mixture with adenosine-5'phosphate, glutathione, biotin and yeast extract (either singly or as a mixture) or with a heated extract of a known active strain (122/33) of Escherichia coli; in no case did any cystathionase activity result. Adenosine-5' -phosphate and glutathionine have been found to reactivate certain amino acid deaminases (Wood \& Gunsalus, 1949). Apparent lack of the enzyme might also be due to the presence of an inhibitor. One 


\section{Cystathionine catabolism}

batch of the cell-free extract was exhaustively dialysed whilst another was fractionated with $50 \%$ ammonium sulphate and both fractions tested after dialysis. All three dialysates were inactive even on addition of pyridoxal phosphate and magnesium ions. Cell-free extracts of the inactive strain (26/18) did not affect the formation of pyruvate from cystathionine by cell-free extracts of an active strain (122/33). This experiment shows not only that strain 26/18 does not contain a dissociable inhibitor but also that it does not contain some additional enzyme which destroys cystathionase itself. Although the possibility cannot be excluded that strain 26/18 contains cystathionase inactivated by an inhibitor which does not dissociate, it is more likely that the enzyme is not formed by this auxotroph.

\section{DISCUSSION}

The properties of methionine auxotrophs of Escherichia coli suggest strongly that cystathionine is an intermediate in the biosynthesis of methionine by this organism (see Introduction). The experiments of Bolton, Cowie \& Sands (1952), who used an isotope tracer technique, however, cast doubt on this view; the addition of unlabelled cystathionine to cultures growing with $\left[{ }^{35} \mathrm{~S}\right]$ sulphate as sole source of sulphur did not, as would be expected, decrease the extent of incorporation of ${ }^{35} \mathrm{~S}$ into methionine. The present work shows that $\boldsymbol{E}$. coli has active enzymic mechanisms for the conversion of cystathionine to homocysteine which is the undoubted immediate precursor of methionine. Other work in this laboratory (Rowbury, 1961, 1962) shows that $\boldsymbol{E}$. coli also has enzymes for the synthesis of cystathionine from precursors (homoserine + cysteine) indicated by nutritional studies with mutants of $\boldsymbol{E}$. coli and other micro-organisms. There remains little doubt therefore that cystathionine is an intermediate and that the results of the isotope experiments must be explained in some other way; it is possible, for example, that exogenous cystathionine may not equilibrate with the cystathionine formed within the organism and perhaps remains tightly bound to the enzyme systems which catalyse its synthesis and further metabolism. The cystathionase was, as expected, not found in a methionine auxotroph of Escherichia coli which responded to homocysteine but not to cystathionine; it was also absent from a similar auxotroph of Neurospora crassa (Fischer, 1957).

Cystathionine could be degraded by the cleavage of the bond which unites the $S$ atom to: either (1) the three-carbon chain with formation of homocysteine, pyruvate and ammonia (Fig. 3, $a$ ); or (2) the four-carbon chain, with formation of cysteine, $\alpha$-ketobutyrate and ammonia (Fig. 3, $d$ ). Mechanism (2) operates in animal tissues while both mechanisms appear to occur in Neurospora crassa and Proteus morganii although (1) predominates (see Introduction). In the present work no evidence for mechanism (2), even as a minor pathway, was found with cell-free extracts of Escherichia coli. It remains possible that such an enzyme is present, but is destroyed during the preparation of the cell-free extract. There is, however, a stable and highly active cystathionase which catalyses mechanism (1).

The cystathionase of Escherichia coli was obtained free from enzymes which form pyruvate from possible initial intermediates (L-serine, L-alanine) formed by hydrolytic or reductive fission of the $\mathrm{S}-\mathrm{C}$ bond (Fig. $3 b, c$ ). Direct formation of homocysteine, pyruvate and ammonia is therefore postulated (Fig. 3a), though it 
remains possible that the unstable $\alpha$-aminoacrylic acid, $\mathrm{CH}_{2}: \mathrm{C}\left(\mathrm{NH}_{2}\right) \mathrm{COOH}$, might be formed transiently; there is isotopic evidence that this compound is an intermediate during the formation of tryptophan from serine and indole by preparations of Neurospora crassa (Tatum \& Shemin, 1954). Matsuo \& Greenberg (1959b), who, using a highly purified crystalline cystathionase from animal tissues and cystathionine labelled with ${ }^{14} \mathrm{C}$ at the $\alpha$-position in the four-carbon chain, obtained no evidence for free homoserine as an intermediate in the formation of $\alpha$-ketobutyric acid, which is the product in this case (Fig. $3 d$ ); these authors also postulated an unsaturated amino acid, vinyl glycine $\left(\mathrm{CH}_{2}: \mathrm{CH} . \mathrm{CH}\left(\mathrm{NH}_{2}\right) \mathrm{COOH}\right)$, as a transient intermediate.

The cystathionase of Escherichia coli, like that of the similar enzyme of Proteus morganii (Binkley \& Hudgins, 1953) and the other type of cystathionase in mammalian liver (Matsuo \& Greenberg, 1959a), required pyridoxal phosphate as coenzyme. Preparations from one strain of $E$. coli (B 166) also required magnesium ions, but this was not demonstrated with either strain $\mathrm{F}$ in the present work or with other strains (R. J. Rowbury, unpublished observations). It is possible that the extracts of $\boldsymbol{E}$. coli strain B 166 contained traces of inhibitory metal ions whose toxicity was overcome by magnesium; Binkley (1950) found that magnesium abolished the inhibitory effect of cupric and ferric ions on a purified thionase enzyme. A non-enzymic cleavage of L-cystathionine to homocysteine, pyruvate and ammonia at $37^{\circ}$ and catalysed by pyridoxal was observed by Binkley (1955); the other conditions necessary were a pH value of 9 and the presence of cupric ions and a chelating agent.

One of us (S. W.) is indebted to the University of Ceylon for study leave during the period of this work. The research was also aided by grants to the Department from the Rockefeller Foundation and the United States Department of Health, Education and Welfare.

\section{REFERENCES}

Anslow, W. P., Srmmonds, S. \& du Vigneaud, V. (1946). The synthesis of the isomers of cystathionine and a study of their availability in sulfur metabolism. J. biol. Chem. 166, 35.

Barton-Wright, E. C. (1952). Methionine, cysteine and tyrosine. In The Microbiological Assay of the Vitamin B-Complex and Amino Acids, p. 142. London: Sir Isaac Pitman and Sons, Ltd.

Binkuey, F. (1950). Enzymatic cleavage of thioethers. J. biol. Chem. 186, 287.

Binkley, F. (1955). Catalytic cleavage of thioethers. J. Amer. chem. Soc. 77, 501.

Binkley, F. \& Hudgins, A. (1953). Comparative studies of sulfur metabolism. Fed. Proc. 12, 178.

Binkley, F., Anslow, W. P. \& DU Vigneaud, V. (1942). The formation of cysteine from LL-S( $\beta$-amino- $\beta$-carboxyethyl)-homocysteine by liver tissue. J. biol. Chem. 143, 559.

Binklex, F., Christensen, G. M. \& Jensen, W. N. (1952). Pyridoxine and the transfer of sulfur. J. biol. Chem. 194, 109.

Bolton, E. T., CowIE, D. B. \&.SAnds, M. K. (1952). Sulfur metabolism in Escherichia coli. III. The metabolic fate of sulfate sulfur. J. Bact. 63, 309.

Carroll, W. R., Stacey; G. W. \& DU Vigneaud, V. (1949). $\alpha$-Ketobutyric acid as a product in the enzymatic cleavage of cystathionine. J. biol. Chem. 180, 375 .

Conway, E. J. \& O'Malley, E. (1942). Microdiffusion methods. Ammonia and urea using buffered absorbents. (Revised methods for ranges greater than $10 \mu \mathrm{g}$. N.) Biochem. J. 36, 655. 
Davis, B. D. \& Mingioli, E. S. (1950). Mutants of Escherichia coli requiring methionine or vitamin $B_{12}$ J. Bact. 60, 17 .

Fischer, G. A. (1957). The cleavage and synthesis of cystathionine in wild type and mutant strains of Neurospora crassa. Biochim. biophys. Acta, 25, 50.

Friedeman, T. E. \& Haugen, G. E. (1943). Pyruvic acid. II. The determination of keto acids in blood and urine. J. biol. Chem. 147, 415 .

Gale, E. F. \& Stephenson, M. (1938). Factors influencing bacterial deamination. II. Factors influencing the activity of DL-serine deaminase in Bacterium coli. Biochem.J. 32, 392.

Gibson, F. \& Woods, D. D. (1960). The synthesis of methionine by suspensions of Escherichia coli. Biochem. J. 74, 160.

Gots, J. S. \& Кон, W. Y. (1950). Methionine synthesis in Escherichia coli. Bact. Proc. p. 134.

Guest, J. R. \& Woods, D. D. (1962). Metabolic interrelationships between cobalamin and folic acid in the synthesis of methionine by Escherichia coli. 2 Europäisches Symposion über Vitamin $B_{12}$ und Intrinsic Factor, p. 686. Ed. by H. C. Heinrich. Stuttgart: Ferdinand Enke Verlag.

Horowitz, N. H. (1947). Methionine synthesis in Neurospora. The isolation of cystathionine. J. biol. Chem. 171, 255.

Lampen, J. O., Roepke, R. R. \& Jones, M. J. (1947). Studies on the sulfur metabolism of Escherichia coli. III. Mutant strains of Escherichia coli unable to utilize sulfate for their complete sulfur requirements. Arch. Biochem. 13, 55.

MARKHAM, R. (1942). A steam distillation apparatus suitable for micro-Kjeldahl analysis. Biochem. J. 36, 790.

Matsuo, Y. \& Greenberg, D. M. (1958a). A crystalline enzyme that cleaves homoserine and cystathionine. I. Isolation procedure and some physicochemical properties. J. biol. Chem. 230, 545.

Matsuo, Y. \& Greenberg, D. M. (1958b). A crystalline enzyme that cleaves homoserine and cystathionine. II. Prosthetic group. J. biol. Chem. 230, 561.

Matsuo, Y. \& Greenberg, D. M. (1959a). A crystalline enzyme that cleaves homoserine and cystathionine. III. Coenzyme resolution, activators and inhibitors. J. biol. Chem. 234, 507.

Matsuo, Y. \& Greenberg, D. M. (1959b). A crystalline enzyme that cleaves homoserine and cystathionine. IV. Mechanism of action, reversibility and substrate specificity. J. biol. Chem. 234, 516.

Metzler, D. E. \& SNell, E. E. (1952a). Deamination of serine. I. Catalytic deamination of serine and cysteine by pyridoxal and metal salts. J. biol. Chem. 198, 353.

Metzler, D. E. \& SNell, E. E. (1952b). Deamination of serine. II. D-Serine dehydrase, a vitamin $B_{6}$ enzyme from Escherichia coli. J. biol. Chem. 198, 363.

Mrckle, H. (1948). Tissue disintegrator. J. roy. micr. Soc. 68, 10.

Mrchell, H. K. (1953). Growth factors in relation to studies of genetics of microorganisms. Symposium on Nutrition and Growth Factors, VIth Congr. int. Microbiol. p. 75 .

Morris, J. G. \& Woods, D. D. (1959). Inter-relationships of serine, glycine and vitamin $B_{6}$ in the growth of mutants of Escherichia coli. J. gen. Microbiol. 20, 576.

Rowbury, R. J. (1961). The synthesis of cystathionine by Escherichia coli. Biochem. J. 81, $42 P$.

Rowbury, R. J. (1962). Control of cystathionine formation in Escherichia coli by methionine. Biochem. J. 82, $24 . \mathrm{P}$.

Stephenson, M. \& Gale, E. F. (1937). Factors influencing bacterial deamination. I. The deamination of glycine, DL-alanine and L-glutamic acid by Bacterium coli. Biochem. $J$. 31, 1316.

Tatum, E. L. \& Shemin, D. (1954). Mechanism of tryptophan synthesis in Neurospora. J. biol. Chem. 209, 671.

Toennies, G. \& KolB, J. J. (1951). Techniques and reagents for paper chromatography. Analyt. Chem. 23, 823. 
WiJesundera, S., Cross, M. J. \& Woods, D. D. (1960). Vitamin $B_{6}$ and glycine in the synthesis of methionine by suspensions of Escherichia coli. J. gen. Microbiol. 22, 786.

WiJesundera, S. \& Woods, D. D. (1953). Cystathionine in relation to methionine synthesis by Bacterium coli. J. gen. Microbiol. 9, iii.

Wood, W. A. \& Gunsalus, I. C. (1949). Serine and threonine deaminase of Escherichia coli: activators for a cell-free enzyme. J. biol. Chem. 181, 171 .

Wood, W. A., Gunsalus, I. C. \& Umbreit, W. W. (1947). Function of pyridoxal phosphate: resolution and purification of the tryptophanase enzyme of Escherichia coli. J. biol. Chem. 170, 313. 